\title{
SOCIAL MECHANISMS OF SCIENTIFIC MANAGEMENT
}

\author{
Dmitry Yadransky', Elena Chumak²
}

\begin{abstract}
The article is devoted to issues of social management in the context of modern industrial and economic transformations. The main purpose of the article is to formulate the author's concept of scientific management using social mechanisms. As a hypothesis, the possibility of implementing scientific management through the use of social norming is considered. The main research methods were general scientific methods of cognition, in particular, dialectic, system, comparative analysis, as well as the induction method in developing the author's concept. The article considers the issue of labour management in conditions of the impossibility of applying quantitative labour standards for intellectual and informational activities. The methodological basis consists of the concepts of foreign and domestic researchers regarding the scientific organization of labour. The concept of social norming is formulated, according to which, managers must ensure the existence of two types of social norms in the organization: rigid (unchanging) and flexible (the content of which varies depending on the current tasks of the organization). Based on the specifics of the labour functions of specific workers, managers can model and implement social norms that stimulate certain social changes. Conclusions. Based on the proposed approach, the nature of managerial influence is determined, which consists of two parts: development and implementation of social norms; stimulation of its fastest assimilation by all members of the labour collective.
\end{abstract}

Key words: management, functions, social norms, efficiency, social requirements, goals.

JEL Classification: M12, M14

\section{Introduction}

In the modern management space, issues of the search for internal reserves are one of the acutest. The situation is aggravated by the fact that in the conditions of a permanent social crisis, social and psychological attitudes of workers shift. Because of this, economic methods become of particular value. However, in conditions of crisis processes, the use of economic management methods is not always possible or appropriate (Kalabina, 2016). Therefore, there is a need to develop managerial approaches based on other mechanisms (including social). The novelty of the topic lies in the fact that in the framework of this study, it is proposed to move away from the methods of technical regulation of labour as the basis of scientific organization and the author's concept of labour organization based on alternative principles is formulated.

The need to develop the proposed concept is explained by the dynamics of changes in the structure of the employed population with a constant increase in the share of intangible production, which significantly complicates the assessment of labour results for the effective application of economic methods. The growth of the intellectual component of the modern labour process significantly reduces the possibility of using clearly structured mechanisms for its regulation (primarily labour regulation). Herewith, the overwhelming majority of scientific concepts (including lean manufacturing, SM) are based on an artefact, the absence of which increasingly characterizes the result of labour activity.

The relevance of scientific decisions lies in the fact that there is a need to rethink the concept of scientific management from the standpoint of the dominance of an intangible product over a tangible one. The last thesis applies both to the process and to the result of labour.

Thus, the purpose of the study is to analyse social aspects of scientific management for types of labour that have lost (are losing) an artefact as a result of the activity. To achieve this goal, it is necessary to solve a number of research problems: to formulate social aspects of scientific management, to study the transformation of approaches to scientific management, in relation to information work, to propose an algorithm of managerial impact in accordance with the modern specifics of work. The methodological basis of the research is based both on the classical principles of scientific management laid down by Taylor, Gastev, and their followers, as well as on the results of the author's research described in previous works (Yadransky, 2012).

\footnotetext{
Corresponding author:

${ }^{1}$ Ural State University of Economics, Russian Federation.

E-mail: jadransky@yandex.ru

${ }^{2}$ Ural State University of Economics, Russian Federation.

E-mail: lena22021977@yandex.ru
} 
The logic of the material studied is based on the fact that the application of quantitative methods of norming and organization of labour for types of labour that do not have an artefact as a result is unproductive, due to which there is an objective need to develop combined methods. The essence of these methods should be reduced to a combination of social self-organization of workers and mechanisms of external regulation of the labour process.

Considering the stated goals, it should be noted that most theoretical and applied research in modern scientific literature is focused on social management in conditions of large social groups, usually institutionally designated (collective of the enterprise, population of the territory). At the same time, these issues in small groups (which, for example, are brigades, project teams) are based mainly on the classical methods of tangible incentives and technical regulation of labour. On the one hand, this is due to the fact that the social management system requires a sufficiently qualified management entity, and on the other, the lack of specific universal methodological recommendations for social management of small labour groups. As the authors of the article rightly note: "Today, the employer is interested in an employee who has the abilities, knowledge, experience, competencies, relationships, and connections - which forms the intellectual capital of the company" (Ryabcev, Kochergina, Khokholush, 2017). Therefore, we are talking about the growth of social requirements for the employee by the employer, in the absence of real criteria for assessing the effectiveness of their implementation.

\section{Methodological problems of the scientific management of information work}

For the application of classical management methods in the modern labour process, there are a number of limitations:

- in the conditions of informational (intellectual) work, its result is, to a large extent, is difficult to formalize (especially within individual performers);

- labour result may turn out to be little predictable and dependent on external conditions (in which the labour process takes place directly);

- the result of intellectual work is largely determined by social norms and values of the social environment in which labour occurs. In other words, each participant in the labour process can have unique personal experience, various social norms and values, which in combination with the norms of other workers can lead to both growth and decrease in the overall productivity of the group;

- external (by managers) and internal (by the employee) assessment of labour results may not coincide.

Given the differences formulated, for operator-based labour, such differences can be neglected. However, in the conditions of creative work, the above discrepancies directly affect all management processes.

Based on the logical differences of the informationmanagement labour process and the process of physical reproduction, we can state their only fundamental difference - the absence of a material artefact. Herewith, the indicated processes are of a cyclic nature, which proceeds in time. At the same time, the information and management labour process (work cycle) can vary significantly in duration.

The duration of the work cycle of an individual managerial employee may vary significantly depending on the characteristics of his professional functions. So, the duration of the work cycle of the chief accountant, in our opinion, is 1 year because it contains work related to the preparation of the annual report (the frequency of which is 1 year). At the same time, the work of the call centre operator, who provides telephone counselling to customers, is repeated 100 times or more during the shift in some cases. However, the nature of the information (even in the context of its standardized provision) is constantly changing. Accordingly, an individual operator cycle will be faster than an accountant. On the one hand, this leads to faster acquisition of experience (professional, communicative, social), and on the other hand, it causes a more rapid increase in fatigue over the constant repetition of the work cycle (monotony, possible feeling of the low social significance of work).

It should be noted that for the information management work process, the result is communication (information increment). Moreover, the operator during the work cycle has a standardized character and is reduced to the transfer of information, which leads to a low social significance of such work cycle. The problem of preparing an annual report concerns the chief accountant, however, a separate accountant can prepare certain types of reports, which will make the work of a particular accountant more cyclical and the cycle time - shorter (with a corresponding reduction in the social content of the corresponding cycle). Herewith, for both the operator and the chief accountant, the structure of the work cycle consists of separate microcycles (which can have clear time behaviour). The structure of the operation, the optimal sequence and duration of individual elements can be established using SIPOC or other methods of managerial optimization. Duration can be determined both expertly and using methods for studying the costs of working time. The main difficulty of this approach is to determine the social significance of the labour function.

The change of cycles, together with the acquisition of social experience, causes the accumulation of employee fatigue. Even fatigue does not always occur as a result of a certain type of work, but often as a result of its constant repetition. This phenomenon is true and proven for elements of labour processes (Pozdnyakov, Kozlovcev, Mukhamedzhanova, 2013); however, it may 
fully be inherent in social and professional experience (including professional burnout). Therefore, the above affects the entire process of labour activity and should be taken into account in social management.

\section{Social mechanisms of scientific management}

It should be said that as a kind of norm, for using in the standardization of intellectual work, one can use the change in the duration of individual labour cycles (relative to the standard duration). In our opinion, this approach creates the prerequisites for assessing the possible accumulated fatigue and social experience gained (social competence of the employee). It should also be emphasized that the role of the individual significantly increases in informational work, which is why there is a need for the personification of norms (adaptation to the value-motivational orientations of the individual). Such personification can be achieved by studying the social causes of individual effectiveness and individual labour behaviour.

As Ukrainian researcher V. Pilipenko notes, in modern management, the labour behaviour of workers comes to the fore (Pilipenko, 1993). Since labour behaviour is a type of social behaviour, it is based on labour standards and values that are acquired in the process of labour interaction in a specific labour group. Taking into account the fact that depending on the nature of the professional activity, norms may differ, there may be certain specific norms (values) in a separate labour group. Moreover, the system of norms and values is relatively dynamic, which necessitates its preliminary study (before the start of managerial impact).

Considering the issue of social mechanisms of scientific management, the opinion of P. Drucker is noteworthy, according to which "the productivity of a mental worker becomes the goal of personnel management, as increasing the productivity of a low-skilled worker has been the goal of personnel management for the past century, since the time of F. Taylor. This will require, among other things, completely different approaches to those working in the organization and to their work. Namely: people do not need to be 'controlled.' The task - to guide people. The goal - to make the specific habits and knowledge of each individual employer as productive as possible" (Drucker P.F., 2000). In our opinion, we should talk about social conditions in which the labour actions of employees correlate as much as possible with the expectations of employers. Accordingly, the main discrepancy in this vein (between the employee and the employer) may be not the content of the elements of the labour cycle but its duration or social significance.

Under the conditions of individualized informational (intellectual) work (freelance, remote workplaces), the problem of finding mechanisms for influencing the individual normative field of an employee arises. In this context, we propose to consider means of scientific management, on the one hand, self-standardization, and on the other, the active declaration of desired practices (their intensity), with the goal of "embedding" the expectations of employers in the system of individual life values (social norms) of individual workers.

As V. E. Pilipenko rightly noted: in a superindustrialized society, the main thing is information and creativity. This changes, among other things, the nature of labour, which requires an employee of a new type. The "third wave" worker is more independent, more agile, and no longer an appendage of the machine" (Pilipenko, 1993). Partially agreeing that the worker ceases to be an "appendage of machines", we consider it appropriate to note that the reason for standardization was precisely the need to synchronize a person and a machine. In the conditions of classical labour, there is a need to synchronize the psycho-emotional (intellectual) processes of various workers.

It is possible to consider the social norm characterizing the expected result or the labour process, as well as the intensity of labour cycles, as objective factors of information work. Being aware of the existence of specific requirements (and not statements of the type "you need to work efficiently"), it is easier for an employee to agree (abandon) to a certain type of activity based on a personal value-norm base. The absence of a declared norm can lead to the fact that optimization of one's own effectiveness can come into a certain dissonance with the value orientations of other members of the collective. Such an approach, in our opinion, will cause a conflict (in A. Zdravomyslov's classification - a conflict at the level of everyday life) because such conflicts are associated with the use by people of new opportunities for self-affirmation, with complex processes of adaptation to values, norms, and requirements, consisting for the first time (Zdravomyslov, 2003). Therefore, the establishment of a social norm (intensity, effectiveness, importance) of labour is an important component of scientific management. In this case, we are talking about the norm - a guideline.

However, having established the norm, it is necessary to give the workers a mechanism (tools) to achieve it. One of such mechanisms may be the creation of a selfnorming system (the formation of the skills of such activities in employees). For people of intellectual labour, self-standardization is more represented by time management (Klemens, 2007).

Summarizing the considered literary sources in this area, time management is understood as effective planning of working time to achieve goals, finding temporary resources, prioritizing and monitoring the implementation of planned (Arkhangelskij, 2005). These approaches largely coincide with modern approaches to labour standardization (except the standardization object). In fact, the main difference is that time management is aimed at independently regulating own labour process (while external assistance is recognized as necessary). The usual labour 
standardization is aimed at managing the efficiency of the work process of a group of averaged performers, increasing not only individual but also group efficiency.

Appealing to the classic of Soviet standardization, A. Gastev (Bodrov, 2010), who considers increasing organizational effectiveness as a whole, from the personal effectiveness of an individual ("narrow base"), one can note some utopianism of this logic. The author proposes the logic of increasing the efficiency of the team through the aspirations of individual workers for maximum productivity. If all members of the group have such an aspiration, a consensus is possible but if there are contradictions - a social conflict is inevitable. Accordingly, an artificial rapprochement of individual and group aspirations (norms, values), including those aimed at increasing personal effectiveness, is required. Turning to another classic P. Kerzhentsev who initiated the movement for the individual saving of working time (Bodrov, 2010), one can also ascertain the archaic nature of his views for the conditions of normalization of information and management work. Individual savings are possible either in the conditions of constant changes in the parameters of a labour organization (which is impossible) or in conditions of collective time-saving. Especially ineffective this process will be as the degree of division of labour increases. An exception may be the situation in which such savings act as a group value. Otherwise, such savings will be considered as contrary to the interests of the team (as empirical confirmation, the results of a survey conducted by I. Burov, according to which up to $70 \%$ of respondents think only of themselves) (Vorona, Suimenko, Pilipenko, 2001). At the beginning of the XX century, unlike foreign researchers in scientific management, A. Gastev regarded the worker as an active source of improving labour methods. This was reflected in his concept of the labour attitude. Thus, the social aspects of scientific management by Gastev can be represented as follows:

- ensure the manifestation of the personal initiative of each employee in improving the efficiency of use of working time;

- ensuring each employee's attention to issues of increasing production efficiency ("take to heart");

- standardization in increasing not only "mechanical" but also "creative" efficiency contributes to the conversion of the unspent physical energy of the employee, in the course of performing direct (mechanical) labour processes, into creative energy. It's advisable to spend such energy on improving the efficiency of the entire economic activity of the enterprise (AU. - quality control circles) (Yadransky, 2012). Under the conditions of intellectual labour, the last thesis is archaic; however, it is interesting in that it considers the possibility of the transition of one form of labour activity to another (physical to mental).

Considering social management from socioengineering positions, we can talk about a change in social norms (values) that cause a certain social behaviour of the employee. Moreover, most modern theorists of labour organization do not consider the individual in the labour process as a source of normsetting and consider only external standardization possible. In our opinion, such a technocratic approach is fundamentally outdated. Personal attitudes in the system of individual values can create prerequisites for finding ways to improve results (guided by an individual success model). In this case, the reason for such a search may be the need for adaptation to the requirements of the social environment (team).

\section{Conclusions and recommendations}

Based on the theoretical analysis, it can be concluded that modern management practice requires the development of alternative approaches to the organization of creative (including managerial) work, taking into account the significant influence of social factors on this labour process.

As a result of the consideration of the first research task, the social aspects of scientific management were determined. As a result of the analysis, it was proposed: - to consider the individual as an open system that has its mission, its strategic and tactical plans, chooses alternative ways to achieve them, and is in the external environment of direct and indirect impact. The specified system should coordinate its goals with the goals and state of the environment to maximize compliance with external parameters;

- scientific management, in this context, comes down to creating conditions for increasing the efficiency of functioning by establishing an open system for declaring expected (recommended) modes of behaviour.

Within the second task, aimed at studying the transformation of approaches to scientific management in relation to information work, it is noted that such studies were conducted by domestic scientists in the first half of the XX century. Integrating the gained experience and modern foreign developments, we see the need to develop social parameters of the work cycle. We include the following parameters:

- labour intensity;

- number of tasks;

- the level of independence of decisions made;

- social significance.

Based on these parameters, it becomes possible to differentiate the categories of workers who do not have an artefact as a result of labour.

Within the scope of the solution of the third task, an algorithm of managerial impact was proposed in accordance with the specifics of social management. The thesis is formulated, according to which the practical implementation of social aspects of scientific management ultimately means the formation of an organizational system of social norms and rules. These standards are divided into two groups: 
- the first - the norms (rules) are persistent and cover the general rules for the joint implementation of labour activities;

- the second - flexible standards. The flexible part of social norms should provide for changes in the regulatory system of the labour group as a response to changes in the external environment. The managerial impact, in this case, will consist of two parts: development and implementation of the social norm and stimulation of its fastest assimilation by all members of the labour collective.

A criterion for the ultimate effectiveness of the social organization of labour is defined - maximization of the social result with minimal aggregate parameters of labour costs (labour intensity, number of tasks). Herewith, the criterion of social effectiveness is the consistency of the actual labour costs of the microgroup with the views of the leadership and organization. The specific forms of managerial influences will be predetermined by the management model selected in a particular organization, the type of organizational culture, as well as a number of other organizational factors.

Scientific management, respectively, will be determined by the criteria of rationality and systematicity. Direct empirical indicators of these criteria should be:

- for rationality - economic stability, profitability, environmental friendliness, productivity, market adequacy (demand);

- for systematicity (parameters of labour intensity, social efficiency, structural optimality, time parameters, adequacy to internal processes of the organization).

The main prospects of the conducted theoretical analysis, in our opinion, are the development of a specific system of social standardization at a particular enterprise. We conduct similar studies at a number of enterprises. Among the categories of workers studied: TED specialists, design engineers, shift foremen, transfer line operators, call centre operators. Practical results of the implementation of this concept will be presented in our next works.

\section{References:}

Arkhangelskij, G. A. (2005). Tajm-menedzhment v sisteme upravleniya organizaciej [Time Management in the Organization Management System]. Moscow: Moskovskaya Finansovo-promyshlennaya Akademiya. (in Russian) Berd, P. (2001). Tajm-menedzhment: planirovanie i kontrol vremeni [Time Management: Time Planning and Control]. Moscow: Fair-press. (in Russian)

Bodrov, B. A. (2010). Razvitie ucheniya o professionalnom utomlenii cheloveka. Chast I. Kategoriya "utomlenie" $\mathrm{v}$ sisteme predstavlenij o funkcionalnom sostoyanii i deyatelnosti cheloveka [Development of the Doctrine of Professional Human Fatigue. Part I. The Category of "Fatigue" in the System of Ideas about the Functional State and Activities of Man]. Psikhologicheskij zhurnal, 31(3), 46-57. (in Russian)

Gastev, A. K. (1972). Kak nado rabotat [How to Work]. Moscow: Ekhonomika. (in Russian)

Drucker, P. F. (2000). Zadachi menedzhmenta v XXI veke [Management Challenges for the 21st Century]. Moscow: Vilyams. (in Russian)

Zajvert,L.J. (2007).Eslispeshish-netoropis. Novyjtajm-menedzhmentv uskorivshemsya mire. Sem shagovk effektivnosti i nezavisimosti $v$ ispolzovanii vremeni [Slow Down to Speed Up: How to Manage Your Time and Rebalance Your Life]. Moscow: AST : Astrel. (in Russian)

Zdravomyslov, A. G. (2003). Chelovek i ego rabota v SSSR i posle [Man and His Work in the USSR and After]. Moscow: Aspekt-press. (in Russian)

Kalabina, E. G. (2016). Adaptaciya povedeniya predpriyatiya $\mathrm{v}$ sfere oplaty truda i zanyatosti $\mathrm{v}$ rossijskikh ekonomicheskikh realiyakh [Adaptation of Enterprise Behaviour in the Field of Remuneration and Employment in Russian Economic Realities]. Upravlenecz, 6(64), 26-31. (in Russian)

Klemens, Dzh. K. (2007). Vlast nad vremenem: za predelami tajm-menedzhmenta: kak stat effektivnym rukovoditelem, izmeniv svoe otnoshenie ko vremeni [Time Mastery: How Temporal Intelligence Will Make You a Stronger, More Effective Leader]. Moscow : Dobraya kn. (in Russian)

Pilipenko, V. E. (1991). Organizaciya. Trud. Effektivnost [Organization. Labour. Efficiency]. Kiev: Naukova dumka. (in Russian)

Pilipenko, V. E. (1993). Socialnaya regulyaciya trudovogo povedeniya (sociologicheskij analiz) [Social Regulation of Labour Behaviour (Sociological Analysis) ]. Kiev: Naukova dumka. (in Russian)

Pozdnyakov, V. D., Kozlovcev, A. P., \& Mukhamedzhanova, G. Sh. (2013). Vliyanie utomlyaemosti na rabotosposobnost i funkcionalnuyu nadyozhnost operatorov zhivotnovodstva [The Effect of Fatigue on the Performance and Functional Reliability of Livestock Operators]. Izvestiya orenburgskogo gosudarstvennogo agrarnogo universiteta, 4(42), 83-85. (in Russian)

Vorona, V. M. (2001). Promyshlennoe predpriyatie i ego lyudi: problemy socialno-ekonomicheskogo povedeniya [Industrial Enterprise and Its People: Problems of Socio-Economic Behaviour]. Kiev: In-t sociologii NAN Ukrainy. (in Russian) Ryabcev, A. Yu., Kochergina, T. V., \& Khokhlush, M. S. (2017). Vozmozhnosti obrazovatelnoj sredy v formirovanii intellektualnogo kapitala [The Possibilities of the Educational Environment in the Formation of Intellectual Capital]. Upravlenecz, 1(65), 60-65. (in Russian)

Yadransky, D. N. (2012). Norma truda: sociologicheskoe izmerenie: monogr. [Worktime Standard: Sociological Dimension: Monograph]. Zaporozhe: Prosvita. (in Russian) 